\title{
Bay anchovy Anchoa mitchilli in Narragansett Bay, Rhode Island. II. Spawning season, hatch-date distribution and young-of-the-year growth
}

\author{
Amy E. Lapolla* \\ Box 200, University of Rhode Island, Graduate School of Oceanography, South Ferry Road, Narragansett, \\ Rhode Island 02882, USA
}

\begin{abstract}
Seasonality becomes more pronounced with increasing latitude, so that at northern sites organisms must adapt to a shorter growing season and more extended and severe overwintering conditions. Narragansett Bay (Rhode Island, USA) lies near the northern extent of the range of the bay anchovy Anchoa mitchilli, an abundant member of this estuarine system during the summer months. The length of the spawning season, hatch-date frequency, and young-of-the-year (YOY) growth rates were evaluated for Narragansett Bay anchovies during the summer of 1997 by gonadosomatic indices (GSI) and otolith-increment analysis. GSI data indicated a shorter spawning season for this species in Narragansett Bay than at lower latitudes. Otolith-increment analysis data indicated that hatch-datefrequency was highest in July. Mean YOY growth rate $\left(0.70 \mathrm{~mm} \mathrm{~d}^{-1}\right)$ was much higher at this latitude than for conspecifics in Chesapeake Bay $\left(0.47 \mathrm{~mm} \mathrm{~d}^{-1}\right)$. One possible adaptation to a shorter growing season is an increased growth rate during favorable conditions.
\end{abstract}

KEY WORDS: Bay anchovy · Anchoa mitchilli - Spawning season - Countergradient variation · Otolith-increment analysis · YOY growth

\section{INTRODUCTION}

The bay anchovy Anchoa mitchilli is an important member of coastal bay and estuarine communities throughout its range, which extends along the western North Atlantic from Maine to Florida and around the Gulf of Mexico to Yucatan (Hildebrand 1943, 1963). At higher latitudes, inshore abundance of bay anchovy becomes seasonal, peaking in the summer months, with fall migrations offshore to deeper water (Hildebrand 1963). The estuarine system of Narragansett Bay, Rhode Island (see Fig. 1 in Lapolla 2001, this issue) lies near the northern extent of the range of this species (Bigelow \& Shroeder 1953). The bay anchovy almost certainly plays an important role in the trophic dynamics of the Bay community, where it may be the most abundant finfish species during the summer

*E-mail: amyla@gso.uri.edv and amylapolla@hotmail.com months (Rhode Island Department of Environmental Management, Division of Fish and Wildlife [RIFW], Narragansett Bay, unpubl. data). While a great deal of information exists regarding the biology and ecology of this species at lower latitudes, the anchovies of Narragansett Bay have remained virtually unstudied.

Environmental factors, which vary latitudinally, will potentially result in intraspecific differences in successful phenotypes over an extensive latitudinal range. There is a growing body of literature in support of intraspecific phenotypic (as well as genotypic) latitudinal variation in such traits as vertebral number, growth rate, and energy storage in a number of fish species (Conover 1990, Conover \& Present 1990, Billerbeck et al. 1997, Conover et al. 1997, Schultz \& Conover 1997). A large fraction of this literature is based on another small coastal fish, the Atlantic silverside Menidia menidia (Conover \& Present 1990, Present \& Conover 1992, Billerbeck et al. 1997, Schultz \& Conover 1997). 
Particularly well studied in Menidia menidia is latitudinal variation in growth rate. Termed 'countergradient variation in growth rate', the shorter growing season encountered by fishes at higher latitudes appears to be compensated for by elevated growth rates during favorable conditions (Conover \& Present 1990). There is a genetic basis for latitudinal differences in growth efficiency (Conover \& Present 1990); this intraspecific variability has probably been generated by the selective pressure of size-dependent winter mortality (Conover \& Present 1990, Present \& Conover 1992, Schultz et al. 1998). Selection by overwinter mortality may act most strongly on the evolution of growth rate during the juvenile life stage (the first growing season), as juveniles must reach a minimum size in order to migrate and overwinter successfully (Schultz et al. 1998).

Although Anchoa mitchilli and Menidia menidia are not closely related taxonomically, they share similar life-history characteristics as small, short-lived coastal fishes. Both species exist over an extensive latitudinal range (Bigelow \& Shroeder 1953), the northern reaches of which have pronounced seasonal fluctuations in environmental conditions (e.g. temperature, food availability). Since both species have similar lifehistory traits including seasonal offshore migration, and are subject to similar selection pressures, the bay anchovy may also exhibit a countergradient growth rate variation.

As a first step in investigating intraspecific latitudinal differences in life-history traits of Anchoa mitchilli, particularly growth rate, the objectives of this study included: (1) definition of the spawning season of this species in Narragansett Bay, (2) determination of hatchdate frequency and growth-rates for young-of-the-year (YOY), and (3) preliminary comparison of these results with similar data obtained for conspecifics at lower latitudes, in particular those of Zastrow et al. (1991).

\section{METHODS}

Field collections. Anchoa mitchilli were collected at monthly intervals from May through October of 1997 at each of 13 stations within Narragansett Bay by the RIFW. At each station, fish were collected with an otter trawl equipped with a $0.625 \mathrm{~cm}$ mesh cod-end towed for $20 \mathrm{~min}$ at approximately $4.6 \mathrm{~km} \mathrm{~h}^{-1}$. Captured fish were counted, individual fork lengths were measured (nearest $\mathrm{cm}$ ), and total anchovy biomass (kg) was recorded. A random subsample of anchovies was chilled on ice, brought back to the laboratory, and preserved in 95\% ethanol. Several additional samples were collected during the RIFW juvenile finfish survey with a $60 \mathrm{~m}$ beach seine $($ depth $=3 \mathrm{~m}$; mesh size $=$ mesh size $=0.5 \mathrm{~cm}$ bag,
$0.625 \mathrm{~cm}$ body), and by the University of Rhode Island Graduate School of Oceanography Narragansett Bay trawl survey ${ }^{1}$ with an otter trawl (tow duration $=30 \mathrm{~min}$; tow speed $=4.6 \mathrm{~km} \mathrm{~h}^{-1}$; cod end mesh size $=2.5 \mathrm{~cm}$ ). Some of these additional samples were frozen for up to a week before being preserved in $95 \%$ ethanol.

Laboratory procedures. Within 2 wk of collection, the fork length (FL, nearest $\mathrm{mm}$ ) and wet weight (nearest $0.01 \mathrm{~g}$ ) were measured for up to 100 randomly selected adult anchovies from each station. Once YOY anchovies were recruited to the trawl in August, the same measurements were taken from approximately 100 YOY individuals from each station (in addition to the 100 adults). Length and weight measurements were not adjusted for potential shrinkage due to death or preservation.

A total of 936 adult fish were sexed by visual gonad examination. Gonads were removed from up to 10 fish from each length class, and blotted wet weight of the gonads was measured (nearest $0.01 \mathrm{~g}$ ). Gonads were taken from males and females at random.

Gonadosomatic indices. Gonadosomatic indices (GSI) were calculated on an individual-fish basis as:

$$
\operatorname{GSI}(\%)=100\left[w t_{\mathrm{G}} /\left(w t_{\mathrm{B}}-w t_{\mathrm{G}}\right)\right]
$$

where $w t_{\mathrm{G}}=$ gonad weight $(\mathrm{g})$ and $w t_{\mathrm{B}}=$ whole-fish blotted wet weight $(\mathrm{g})$. These values were used as an indicator of the duration and relative intensity of fish spawning. Individual values were averaged on a monthly basis; mean values were calculated with sexes pooled as well as taken separately. Mean values were compared between sexes with a Student's $t$-test assuming equal variance, or assuming unequal variance when an F-ratio test indicated that the assumption of equal variance was not valid.

YOY otolith analysis. Sagittal otoliths of as many as 5 fish from each $5 \mathrm{~mm}$ YOY length-class caught at each station/date, were removed, mounted in thermoplastic (Crystal-Bond) on microscope slides, and polished in the sagittal plane with 9 to $12 \mu \mathrm{m}$ lapping film (3M Imperial) followed by $0.3 \mu \mathrm{m}$ alpha alumina paste (Union Carbide Buehler micropolish). Daily increments (a light zone of growth followed by a dark discontinuous zone) were counted with a compound microscope under $400 \times$ to $1000 \times$ magnification. Daily otolith increments are deposited in larval bay anchovy starting at 2 or 3 d post-hatch (Fives et al. 1986, Leak \& Houde 1987). A total of 174 YOY was successfully aged to the nearest day by this method. The mean number of fish aged per length class was $\sim 22$, with a maximum of 34 fish ( 25 to $29 \mathrm{~mm}$ length class) and a minimum of 5 fish (55 to $59 \mathrm{~mm}$ length class).

\footnotetext{
${ }^{1}$ No YOY were collected by the larger-mesh URI trawl
} 
A subsample of 30 otoliths was read independently by a second reader to check the accuracy and precision of the primary otolith reader. The precision and accuracy of daily increment counts between otolith readers was tested by average percent error methods (Beamish \& Fournier 1981, Chang 1982), and by a chi-square method (Hoenig et al. 1995).

Age, hatch date and growth. Age in days was estimated as the number of increments counted +2 (Zastrow et al. 1991). Hatch dates were determined for aged YOY by back-counting age from capture date.

A hatch date-length key method was developed after the age-length key method discussed by Hilborn \& Walters (1992). Hatch date-length data were partitioned by month of capture and used to construct a hatch date-length key for each month (August to October). The keys were then employed to generate a hatch date frequency distribution (to the nearest week) from all anchovy YOY length data collected by the RIFW trawl survey (entire catch at each station from which I took a subsample) for 1997.

Growth rate was calculated after Zastrow et al. (1991) as:

$$
G=\left(F L_{\text {capture }}-F L_{\text {hatch }}\right) / A
$$

where $G=$ growth rate in $\mathrm{mm} \mathrm{d}^{-1}, A=$ age in days determined by otolith analysis, and $F L_{\text {hatch }}$ is assumed to be $2 \mathrm{~mm}$.

\section{RESULTS}

\section{Spawning season and GSI (\%)}

The spawning season for Anchoa mitchilli in 1997, as defined by GSI, began between mid-May and midJune, peaked in June and July, and ended by midSeptember (Table 1). Mean GSI for males was greatest in July $(10.89 \%)$; mean GSI for females was greatest in June $(9.93 \%)$ (Table 1$)$. The highest GSI value $(24.7 \%)$ was measured for a female in June. Differences between males and females in mean GSI were significant in July (Student's $t$-test assuming unequal variance: $t_{\text {stat }}=-9.03$, df $\left.=324, \mathrm{p} \ll 0.001\right)$, but were not significant for June $(p=0.95)$, August $(p=0.36)$ or September $(p=0.44)$.

\section{Otolith increment counts}

The mean increment counts were not significantly different between the primary otolith reader and a second otolith reader (53.2 increments and 53.3 incre- ments, respectively; $t$-test: $t_{\text {stat }}=0.08, \mathrm{df}=32, \mathrm{p}=0.94$ ). The average percent error (APE) between readers was $6.92 \%$, with a mean coefficient of variation of $9.78 \%$. Less than $10 \%$ error was found between $73 \%$ of counts by both readers. No significant differences were found in a test of symmetry of individual increment counts $\left(\chi^{2}=33, \mathrm{df}=32, \mathrm{p}>0.3\right)$ and increment counts grouped by week $\left(\chi^{2}=14.33, \mathrm{df}=13, \mathrm{p}>0.3\right)$, indicating that neither reader was consistently reading higher or lower. It was therefore determined that counts by the primary otolith reader were acceptable for purposes of estimating growth rates and hatch dates.

\section{Age, hatch date and growth}

Age of YOY ranged from 29 to $84 \mathrm{~d}$. The youngest fish (29 d) collected was $16 \mathrm{~mm} \mathrm{FL,} \mathrm{while} \mathrm{the} \mathrm{oldest}$ YOY (84 d) was $46 \mathrm{~mm}$ FL. The relationship between age and FL of YOY is described by the linear equation:

$$
F L(\mathrm{~mm})=0.589(\operatorname{age}[\mathrm{d}])+5.9868
$$

The frequency of hatch dates for YOY caught from August through October 1997 was highest in mid-July

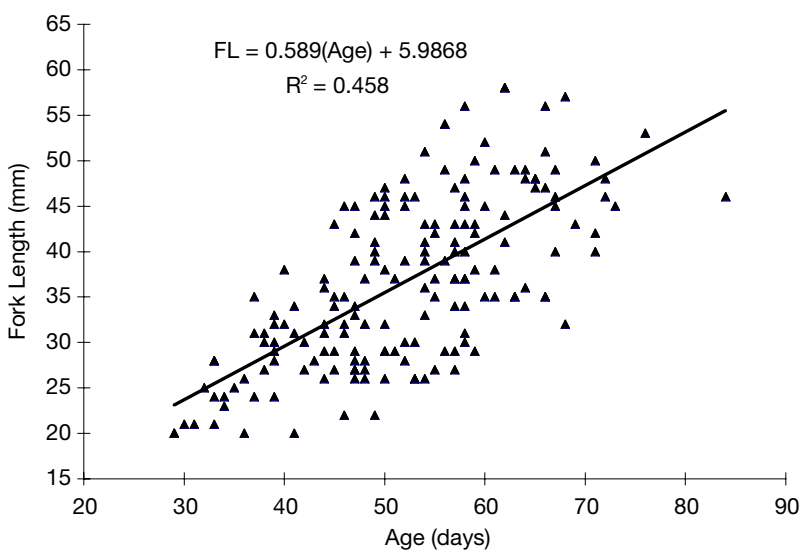

Fig. 1. Anchoa mitchilli. Relationship between age and fork length (FL) of otolith-aged young-of-the-year collected in Narragansett Bay 


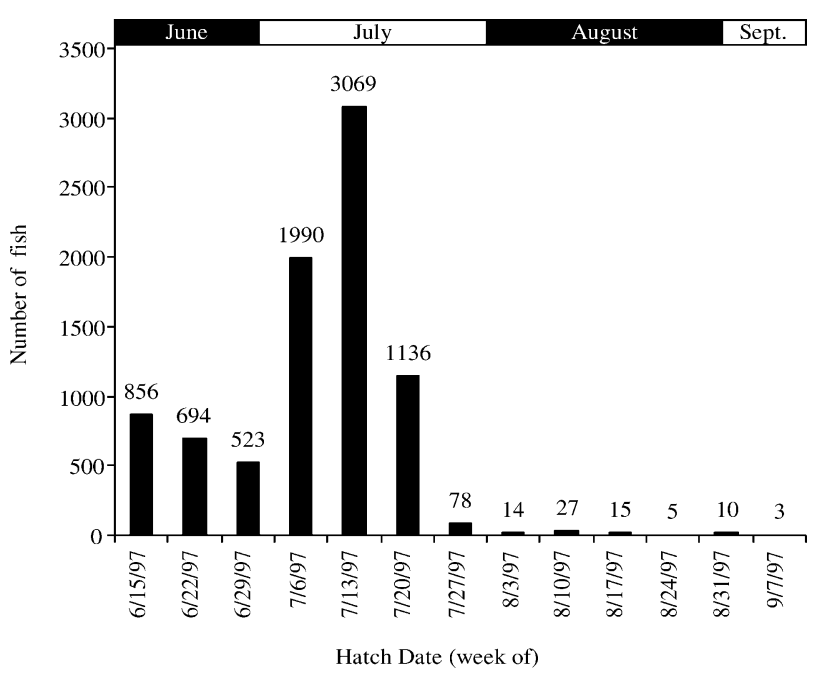

Fig. 2. Anchoa mitchilli. Hatch-date distribution of young-ofthe-year caught during the summer and fall of 1997 in Narragansett Bay. Hatch dates presented in order mo/d/yr

(Fig. 2). Juvenile fish collected were not found to have hatched earlier than mid-June, nor later than early September (Fig. 3).

The range of fork lengths measured to the nearest $\mathrm{mm}$ for YOY in this study was 20 to $58 \mathrm{~mm}$ (Table 2). Mean growth rate for all aged YOY was $0.70 \mathrm{~mm} \mathrm{~d}^{-1}$

Table 2. Anchoa mitchilli. Young-of-the-year fork lengths (Narragansett Bay) and standard lengths (Chesapeake Bay) measured in this study and by Zastrow et al. (1991), respectively. Mean, standard deviation, and range of lengths are presented

\begin{tabular}{|c|c|c|c|c|c|c|c|c|}
\hline \multirow[t]{2}{*}{ Month } & \multicolumn{4}{|c|}{$\begin{array}{c}\text { Narragansett Bay (1997) } \\
\text { Fork length }\end{array}$} & \multicolumn{4}{|c|}{$\begin{array}{l}\text { Chesapeake Bay (1986) } \\
\text { Standard length }\end{array}$} \\
\hline & $\mathrm{n}$ & Mean & $\mathrm{SD}$ & Range & $\mathrm{n}$ & Mean & $\mathrm{SD}$ & Range \\
\hline $\begin{array}{l}\text { Aug-Oct } \\
\text { combined }\end{array}$ & 174 & 36.6 & 9.2 & $20-58$ & 124 & 31.7 & 7.4 & $18-48$ \\
\hline Aug & 62 & 31.7 & 7.4 & $20-46$ & 17 & 25.3 & 6.2 & $18-42$ \\
\hline Sep & 74 & 41.2 & 8.8 & $26-58$ & 64 & 29.0 & 6.1 & $20-47$ \\
\hline Oct & 38 & 36.0 & 8.5 & $22-53$ & 43 & 38.2 & 4.5 & $30-48$ \\
\hline
\end{tabular}

Table 3. Anchoa mitchilli. Young-of-the-year growth rates $\left(\mathrm{mm} \mathrm{d}^{-1}\right)$ for Narragansett Bay and Chesapeake Bay by month of capture. Mean, standard deviation, and range of measurements are presented

\begin{tabular}{|c|c|c|c|c|c|c|c|c|}
\hline \multirow[t]{2}{*}{ Month } & \multicolumn{4}{|c|}{$\begin{array}{l}\text { Narragansett Bay (1997) } \\
\text { (Present study) }\end{array}$} & \multicolumn{4}{|c|}{$\begin{array}{c}\text { Chesapeake Bay (1986) } \\
\text { (Zastrow et al. 1991) }\end{array}$} \\
\hline & $\mathrm{n}$ & Mean & $\mathrm{SD}$ & Range & $\mathrm{n}$ & Mean & $\mathrm{SD}$ & Range \\
\hline $\begin{array}{l}\text { Aug-Oct } \\
\text { combined }\end{array}$ & 174 & 0.70 & 0.14 & $0.39-0.98$ & 124 & 0.47 & 0.04 & $0.36-0.61$ \\
\hline Aug & 62 & 0.71 & 0.14 & $0.39-0.96$ & 17 & 0.45 & 0.04 & $0.36-0.51$ \\
\hline Sep & 74 & 0.74 & 0.12 & $0.48-0.98$ & 64 & 0.48 & 0.04 & $0.38-0.61$ \\
\hline Oct & 38 & 0.61 & 0.11 & $0.45-0.95$ & 43 & 0.47 & 0.03 & $0.42-0.54$ \\
\hline
\end{tabular}

(Table 3). Ranges in growth rate were similar for all months of capture (Table 3).

\section{DISCUSSION}

As defined by GSI (Table 1), the duration of the spawning season of Anchoa mitchilli in 1997 in Narragansett Bay was shorter than that reported for lower latitudes, where spawning may occur year-round (Houde \& Lovdal 1984). In Tampa Bay, Florida, spawning begins once surface-water temperatures reach $20^{\circ} \mathrm{C}$ (generally by early April) and may continue into November (Phillips 1981). Near Beaufort, North Carolina, the spawning season has been found to extend from late April to early September (Kuntz 1914). In Chesapeake Bay, spawning runs from mid-May to mid-August (Zastrow et al. 1991). In Barnegat Bay, New Jersey, and Great South Bay, New York, spawning begins as early as April and is essentially completed by August (Richards 1959, Vouglitois et al. 1987, (1988).

comparison, the reproductive season in Narrasett Bay did not effectively begin until mid-June, as YY individuals were found that had hatched prio to the week of June 15 in 1997 (Fig. 2). Bay anchovy larvae first appeared during June in extensive ichthyoplankton surveys conducted in Narragansett Bay during 1972 and 1973; larval anchovy abundance peaked in July, and there were no larvae captured after August (Durbin \& Durbin unpubl. data). This supports the presence of an abbreviated spawning season for anchovy in Narragansett Bay in comparison to those in lower latitudes. However, there may be interannual variations in the start of the spawning season in Narragansett Bay, depending on the arrival time of anchovies in the Bay. Long-term RIFW trawl data indicate that relatively few bay anchovies enter Narragansett Bay prior to May, and in some years they are not well represented in trawl data until July (RIFW unpubl. data).

Spawning in temperate fish species is often cued by temperature (Moyle \& Cech 1988), and this appears to be the case for the bay anchovy. The commencement of spawning in Narragansett Bay coincides with an increase in water temperature to above $15^{\circ} \mathrm{C}$ (Fig. 3); a similar relationship is suggested by Chesapeake Bay data (Luo \& 
Musick 1991, NOAA 1999). Warming of Narragansett Bay in the early summer is delayed by roughly 1 mo in comparison to Chesapeake Bay, accounting for the latitudinal differences in the timing of the onset of the spawning season.

Peak spawning during July, as indicated by GSI and hatch-date frequencies, may be related to the food environment. The bay anchovy is an 'income breeder', deriving the energy for spawning from daily feeding rather than from fat reserves (Luo \& Musick 1991, Wang \& Houde 1994), and therefore may spawn preferentially in areas with plentiful food (Luo \& Musick 1991, Dorsey et al. 1995, Peebles et al. 1996). Bay anchovies are opportunistic zooplanktivores, consuming larger items (such as crab megalopae, amphipods) when available, although their diet normally consists of various stages of calanoid copepods (Johnson et al. 1990, Peebles et al. 1996). While zooplankton data were not collected as part of the present study, peak zooplankton abundance typically occurs during July in Narragansett Bay (Jeffries 1962, Martin 1965, Hulsizer 1976, Durbin \& Durbin 1981). Peaks in abundance of all life-stages of the summer-dominant copepod Acartia tonsa occur in July in the Bay (Durbin \& Durbin 1981), indicating that food for both adult anchovies (copepodites and adult copepods) and hatching bay anchovy larvae (nauplii) would be abundant during this month. The high representation of July hatch dates in surviving juveniles (Fig. 3) coupled with the trends in zooplankton abundance commonly seen in Narragansett Bay suggest favorable conditions of food availability for bay anchovy spawned in July of 1997.

Similarly, the end of the spawning season, which does not appear to be directly related to temperature (Fig. 3), could be caused by a decrease in prey abundance. The Narragansett Bay zooplankton population is decimated each year by great numbers of ctenophores which enter the Bay at the end of the summer (late August/early September) (Hulsizer 1976, Durbin \& Durbin 1981); competition with ctenophores for food may therefore dictate the end of the spawning season prior to temperature decline in the Bay.

Mean growth rate of YOY found in this study $\left(0.70 \mathrm{~mm} \mathrm{~d}^{-1}\right)$ was much greater than that measured by Zastrow et al. (1991) in Chesapeake Bay $(0.47 \mathrm{~mm}$ $\mathrm{d}^{-1}$ : Table 3). The growth rate of individual YOY anchovies was highly variable, ranging from 0.39 to $0.98 \mathrm{~mm} \mathrm{~d}^{-1}$ in this study, while Chesapeake Bay values ranged from 0.36 to $0.61 \mathrm{~mm} \mathrm{~d}^{-1}$ (Zastrow et al. 1991: Table 3). While the lowest values found in this study are similar to those found for Chesapeake Bay fish, the maximum growth rate in this study was clearly much higher; the majority of YOY individuals examined for the present analysis had growth rates

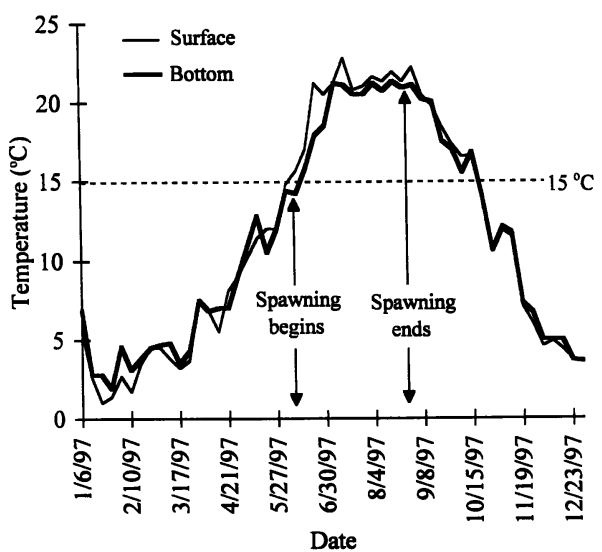

Fig. 3. Temperature data from the Graduate School of Oceanography Narragansett Bay Trawl Survey for 1997. Onset of the spawning season of Anchoa mitchilli as defined by gonadosomatic index and hatch-date data coincides with the increase in water temperature above $15^{\circ} \mathrm{C}$. Hatch dates presented in order $\mathrm{mo} / \mathrm{d} / \mathrm{yr}$

above the maximum measured for Chesapeake Bay YOY anchovies (Table 3).

These data, particularly the higher growth rates of YOY at this study site compared to those measured in Chesapeake Bay suggest that Narragansett Bay provides favorable conditions for reproduction, growth and survival of Anchoa mitchilli during the summer months. The strong representation of July hatch dates (Fig. 2) among fish surviving past the larval stage to be caught as juveniles indicates that these conditions were apparently optimal during July 1997. However, while good growth and survival of anchovy progeny suggest favorable conditions of food and temperature in Narragansett Bay during the summer months, this benefit is likely to be balanced by the challenges of overwintering near the northern extent of the range of this species.

The higher growth rate of juvenile Anchoa mitchilli from Narragansett Bay compared to southern conspecifics may be evidence of countergradient variation in growth rate for this species. Smaller individuals have lower energy stores and higher weight-specific metabolic rates than larger individuals, and are more likely to succumb to overwintering mortality (Oliver et al. 1979, Henderson et al. 1988, Hurst \& Conover 1998, Schultz et al. 1998). A shorter growing season coupled with more severe and extended overwintering conditions at northern latitudes may lead to selection for more rapid growth in northern stocks in comparison to southern conspecifics (Conover \& Present 1990). This selection is probably strongest for YOY fish, which must attain adequate size and energy-stores for overwintering (Schultz et al. 1998). 
While environmental and genotypic influences are impossible to separate in a field study such as this, size-based overwintering mortality has been strongly implicated as a selective agent for an ecologically similar species, Menidia menidia (Conover \& Present 1990, Present \& Conover 1992, Schultz et al. 1998). The data presented here, particularly the markedly higher juvenile growth rate observed in Narragansett Bay compared to that observed in Chesapeake Bay, provide a good case for further investigation of the lifehistory of this species, and of genetic and/or environmental factors which regulate aspects of the life-history that vary with latitude.

Acknowledgements. The author wishes to thank the RIFW and the URI-GSO Fish Trawl for collection of anchovies (especially T. Lynch, C. Powell, R. Mello and J. Hermsen), W. Macy for much practical assistance with otolith work, D. Outram for providing daily increment counts for comparison, and E. Durbin, M. Peck and J. Hermsen for discussion and comments on this manuscript. This work was funded in part by a Joshua MacMillan graduate fellowship.

\section{LITERATURE CITED}

Beamish RJ, Fournier DA (1981) A method for comparing the precision of a set of age determinations. Can J Fish Aquat Sci 38:982-983

Bigelow HB, Shroeder WC (1953) Fishes of the Gulf of Maine. US Fish Wildl Serv Fish Bull 53:1-577

Billerbeck JM, Orti G, Conover DO (1997) Latitudinal variation in vertebral number has a genetic basis in the Atlantic silverside, Menidia menidia. Can J Fish Aquat Sci 54: 1796-1801

Chang WYB (1982) A statistical method for evaluating the reproducibility of age determination. Can J Fish Aquat Sci 39:1208-1210

Conover DO (1990) The relation between capacity for growth and length of the growing season: evidence for and implications of countergradient variation. Trans Am Fish Soc 119:416-430

Conover DO, Present TC (1990) Countergradient variation in growth rate: compensation for length of the growing season among Atlantic silversides from different latitudes. Oecologia (Berl) 83:316-324

Conover DO, Brown JJ, Ehtisham A (1997) Countergradient variation in growth of young striped bass (Morone saxatilis) from different latitudes. Can J Fish Aquat Sci 54: 2401-2409

Dorsey SE, Houde ED, Gamble JC (1995) Cohort abundances and daily variability in mortality of eggs and yolk-sac larvae of bay anchovy, Anchoa mitchilli, in Chesapeake Bay. Fish Bull (Wash DC) 94:257-267

Durbin AG, Durbin EG (1981) Standing stock and estimated production rates of phytoplankton and zooplankton in Narragansett Bay, Rhode Island. Estuaries 4:24-41

Fives JM, Warlen SM, Hoss DE (1986) Aging and growth of larval bay anchovy, Anchoa mitchilli, from the Newport River Estuary, North Carolina. Estuaries 9:362-367

Henderson PA, Holmes RHA, Bamber RN (1988) Size-selective overwintering mortality in the sand smelt, Atherina boyeri Risso, and its role in population regulation. J Fish Biol 33:221-233
Hilborn R, Walters CJ (1992) Quantitative fisheries stock assessment: choice, dynamics and uncertainty. Chapman \& Hall, New York

Hildebrand SF (1943) A review of the American anchovies. Bull Bingham Oceanogr Collect Yale Univ 8(1-4):29-37, $87-91$

Hildebrand SF (1963) Family Engraulidae. In: Olsen YH (ed) Fishes of the western North Atlantic, Part 3. Sears Foundation for Marine Research, New Haven, p 152-248 (Mem Sears Fdn Mar Res)

Hoenig JM, Morgan MJ, Brown CA (1995) Analysing differences between two age determination methods by tests of symmetry. Can J Fish Aquat Sci 52:364-368

Houde ED, Lovdal JA (1984) Seasonality of occurence, foods and food preferences of ichthyoplankton in Biscayne Bay, Florida. Estuar Coast Shelf Sci 18:403-419

Hulsizer EE (1976) Zooplankton of lower Narragansett Bay, 1972-1973. Chesapeake Sci 17:260-270

Hurst TP, Conover DO (1998) Winter mortality of young-ofthe-year Hudson River striped bass (Morone saxatilis): size-dependent patterns and effects on recruitment. Can J Fish Aquat Sci 55:1122-1130

Jeffries HP (1962) Succession of two Acartia species in estuaries. Limnol Oceanogr 7:354-364

Johnson WS, Allen DM, Ogburn MV, Stancyk SE (1990) Short-term predation responses of adult bay anchovies Anchoa mitchilli to estuarine zooplankton availability. Mar Ecol Prog Ser 64:55-68

Kuntz A (1914) The embryology and larval development of Bairdella chrysura and Anchovia mitchilli. Bull Bur Fish Wash 33:1-19

Lapolla AE (2001) Bay anchovy Anchoa mitchilli in Narragansett Bay, Rhode Island. I. Population structure, growth and mortality. Mar Ecol Prog Ser 217:93-102

Leak JC, Houde ED (1987) Cohort growth and survival of bay anchovy Anchoa mitchilli larvae in Biscayne Bay, Florida. Mar Ecol Prog Ser 37:109-122

Luo J, Musick JA (1991) Reproductive biology of the bay anchovy in Chesapeake Bay. Trans Am Fish Soc 120 $701-710$

Martin JH (1965) Phytoplankton-zooplankton relations in Narragansett Bay. Limnol Oceanogr 10:185-191

Monteleone DM (1988) Trophic interactions of ichthyoplankton in Great South Bay, NewYork. PhD dissertation, State University of New York, Stony Brook

Moyle PB, Cech JJ Jr (1988) Fishes: an introduction to ichthyology. Prentice-Hall, Englewood Cliffs, NJ

NOAA (National Oceanic and Atmospheric Administration) (1999) National Oceanographic Data Center coastal water temperature guide. http://www.nodc.noaa.gov/dsdt/ wtg12. html (9 Apr 1999)

Oliver JD, Holeton GF, Chua KE (1979) Overwinter mortality of fingerling smallmouth bass in relation to size, relative energy stores, and environmental temperature. Trans Am Fish Soc 108:130-136

Peebles EB, Hall JR, Tolley SG (1996) Egg production by the bay anchovy Anchoa mitchilli in relation to adult and larval prey fields. Mar Ecol Prog Ser 131:61-73

Phillips TD (1981) Spawning season of the bay anchovy, Anchoa mitchilli (Valenciennes), in Tampa Bay, Florida, determined from egg and larval surveys. Fla Sci 44:21

Present TMC, Conover DO (1992) Physiological basis of latitudinal growth differences in Menidia menidia: variation in consumption or efficiency? Funct Ecol 6:23-31

Richards SW (1959) Pelagic fish eggs and larvae of Long Island Sound. Bull Bingham Oceanogr Collect Yale Univ 17:95-124 
Schultz ET, Conover DO (1997) Latitudinal differences in somatic energy storage: adaptive responses to seasonality in an estuarine fish (Atherinidae: Menidia menidia). Oecologia (Berl) 109:516-529

Schultz ET, Conover DO, Entisham A (1998) The dead of winter: size-dependent variation and genetic differences in seasonal mortality among Atlantic silverside (Atherinidae: Menidia menidia) from different latitudes. Can J Fish Aquat Sci 55:1149-1157

Editorial responsibility: Kenneth Sherman (Contributing Editor), Narragansett, Rhode Island
Vouglitois JJ, Able KW, Kurtz RJ, Tighe KA (1987) Life history and population dynamics of the bay anchovy in New Jersey. Trans Am Fish Soc 116:141-153

Wang SB, Houde ED (1994) Energy storage and dynamics in bay anchovy Anchoa mitchilli. Mar Biol 121:219-227

Zastrow CE, Houde ED, Morin LG (1991) Spawning, fecundity, hatch date frequency and young-of-the-year growth of bay anchovy Anchoa mitchilli in mid-Chesapeake Bay. Mar Ecol Prog Ser 73:161-171

Submitted: October 4, 2000; Accepted: November 17, 2000 Proofs received from author(s): July 16, 2001 